Research Article

\title{
Cotton Yield and Lint Response to Tillage System and Irrigation Interval under Wheat Based Cropping System
}

\author{
Niamat Ullah Khan ${ }^{1 *}$,Umbreen Shahzad ${ }^{2}$, Azhar Abbas Khan², Sami Ullah², Muhammad Arshad Farooq², \\ Muhammad Kashan ${ }^{2}$ and Shitab Khan ${ }^{2}$
}

\begin{abstract}
${ }^{1}$ PCCC, Cotton Research Station, Dera Ismail Khan, Pakistan; ${ }^{2}$ College of Agriculture, Bahauddin Zakaria University, Bahadur Campus, Layyah, Pakistan; ${ }^{3}$ Agricultural Research Institute, Ratta Kulachi, Dera Ismail Khan, Pakistan.
\end{abstract}

\begin{abstract}
Water shortage is becoming a serious concern for all crops and particularly for cotton, which has been a major export contributor of Pakistan. In this scenario, reduced tillage could be the best option. A field experiment was conducted during 2019 to study the impact of two tillage systems [reduced $(10 \mathrm{~cm}$ depth, one tiller followed by rotavator) and conventional $(20 \mathrm{~cm}$ depth, including disc plough, cultivator, rotavator, and levelling operations)] and five irrigation intervals (10,15, 20, 25 and 30 days) on cotton yield and lint percentage. Total irrigation water used in irrigation treatments, 10, 15, 20, 25 and 30 days intervals were $1125,750,560,450$ and $360 \mathrm{~mm}$, respectively. Results indicated that reduced tillage had higher plant population (32454), plant height $(114.8 \mathrm{~cm})$, bolls per plant $^{\mathrm{s}}(18.9)$, bolls weight $(2.42 \mathrm{~g})$, seed cotton yield $(1812 \mathrm{~kg} \mathrm{ha}$ ) and lint percentage $(36.72 \%)$ than conventional tillage. Likewise, frequent irrigation interval of 10 days produced taller plants compared to less frequent irrigations (20-25 days). Irrigation at 20 days interval improved seed cotton yield (48.7\%) and lint \%age (21.1\%). Interaction effects (tillage $\mathrm{x}$ irrigation) revealed that reduced tillage with 20 days irrigation interval conserved $60 \%$ more water, produced $60.4 \%$ more bolls per plant, $45.8 \%$ heavier boll weight, $21.1 \%$ higher lint \%age and $41.6 \%$ higher seed cotton yield compared to all other combinations. In conclusion, reduced tillage with 20 days irrigation interval is more advantageous and adaptable in agro-ecological conditions of Dera Ismail Khan.

Received | October 09, 2020; Accepted | August 21, 2021; Published | January 14, 2022

*Correspondence | Niamat Ullah Khan, PCCC, Cotton Research Station, Dera Ismail Khan, Pakistan; Email: drkhancrs@gmail.com

Citation | Khan, N.U., U. Shahzad, A.A. Khan, S. Ullah, M.A. Farooq, M. Kashan and S. Khan. 2022. Cotton yield and lint response to tillage system and irrigation interval under wheat based cropping system. Sarhad Journal of Agriculture, 38(1): 372-378.

DOI | https://dx.doi.org/10.17582/journal.sja/2022/38.1.372.378

Keywords $\mid$ Tillage, Irrigation intervals, Cotton, Seed cotton yield, Lint percentage
\end{abstract}

\section{Introduction}

$\mathrm{C}$ otton (Gossypium birsutum L.) is an important cash crop of Pakistan (Ashraf et al., 2018). It supplies raw materials to textile industries and is called silver-fiber due to its unique quality. Cotton is used in garments, medicines and furnishings of homes. Pakistan is the $5^{\text {th }}$ biggest cotton producers after India, China, United States, and Brazil (Statista, 2018). However, Pakistan is not producing sufficient raw materials for national textile mills. Accordingly,
Pakistan is the first among leading cotton importing countries of the world such as Bangladesh, Turkey, Vietnam, China, and Indonesia (APTMA, 2018). In Pakistan cotton cultivated area has reached to 3 million hectares; share in GDP to $1.5 \%$ and value added to agriculture $7.0 \%$ (MNFSR, 2015). The present area under cotton cultivation with low production per unit area cannot meet even the domestic requirement of the growing population. Since extension of the existing area under cotton may not be possible as already occupied by major crops such as wheat, rice, maize, 
and sugarcane, the possible alternative is to increase cotton yield on the existing area. There are several factors that affect cotton productivity; however, tillage and water are the two key factors that can affect cotton more seriously than all other factors (Ashraf et al., 2018).

Cotton yield can be optimized with suitable tillage and optimum use of irrigation water; however, there is an acute shortage of irrigation water and numerous tillage practices commonly applied for cotton production are not productive. Current water crisis in agriculture gives emphasis on efficient use of water resources (Azevedo et al., 2019). Cotton is a deep rooted crop and the growers consider soil inversion deep tillage necessary for the previous crop residues management. With this practice they also intend to create favourable environment for cotton roots penetration. This practice not only incurs the tillage cost but also causes more use of irrigation water by increasing soil water evaporation. Unlike the prevailing practice, cotton grown with reduced/minimum tillage in the standing stubbles of the previous wheat crop improves water management for cotton by reducing soil water evaporation (Omololu et al., 2020). Roots of the previous wheat crop decompose and create channels through compacted soil layers, which enable subsequent crop roots to grow through the compacted zone and thus improve infiltration (Farooq et al., 2020). Since, water conservation is more in reduced tillage than in conventional tillage (Coates et al., 2021); cotton grown with reduced tillage practices may give economic yield with limited irrigation water at reduced cost of cultivation. Increasing water use efficiency by potential cotton grown with reduced tillage can be an important criterion for enhancing yield under water stressful environment. Several researchers have confirmed positive impact of reduced tillage system on cotton yield, economics and water use efficiency. More recent studies revealed that increased cotton yield and lint percentage under reduced tillage system might be due to improved water use efficiency (WUE), soil fertility, and nutrient status (Tan et al., 2018; Hulugalle et al., 2019).

Cotton is a warm season crop that needs regular supply of water, either from irrigation or rainfall. Successful cotton production depends on availability of water. The world scientists are in search of low inputs agriculture including wise use of irrigation water to optimize production from existing limited water (Thorp et al., 2020). Using inadequate water for enhancing cotton productivity is one of the major challenges for agriculturists (Siskani et al., 2015; Sahito et al., 2019). WUE can be improved by adopting best irrigation management practices (Yang et al., 2016; Idowu et al., 2019). Effective agronomic practice needs to be explored which has the potential to enhance WUE and cotton yield (Li et al., 2019). Since the study area, Dera Ismail Khan, is an arid region and has limited rainfall in addition to low organic matter status of the soil, reduced tillage could be a viable option for efficient use of inadequate irrigation water. Since a little research was done before to investigate the effect of irrigation intervals on cotton under reduced tillage; therefore, the present research was aimed to examine the response of cotton yield and lint under reduced tillage for limited water condition.

\section{Materials and Methods}

\section{Experimental site}

An experiment was carried out at Agriculture Research Institute, Dera Ismail Khan in 2016. Five soil samples were collected randomly from $0-30 \mathrm{~cm}$ soil depth from the study area. The soil samples were analyzed for physico-chemical characteristics. The mstudy area is characterized by hard calcareous soils, high summer temperature $\left(35-40^{\circ} \mathrm{C}\right)$, low annual rainfall $180-250 \mathrm{~mm}$ ) and a $\mathrm{pH}(>7.0)$. Total rainfall during the study year was $215 \mathrm{~mm}$ (Table 1 ).

Table 1: Meteorological data recorded at Cotton Research Station, Dera Ismail Khan during 2019.

\begin{tabular}{lllll} 
Month & \multicolumn{2}{l}{ Temperature $^{\circ} \mathbf{C}$} & & $\begin{array}{l}\text { Rainfall } \\
\text { (mm) }\end{array}$ \\
& Maximum & Minimum & Mean & $(\mathbf{m m}$ \\
April & 45 & 17 & 37.5 & - \\
May & 43 & 25 & 38 & - \\
June & 44 & 27 & 39.25 & 35 \\
July & 39 & 27 & 35.5 & 124 \\
August & 38 & 29 & 34.75 & 173 \\
September & 37 & 25 & 33.5 & 20 \\
October & 34 & 19 & 29.5 & - \\
November & 29 & 14 & 24.5 & - \\
Total & 352 & & &
\end{tabular}

Source: Arid Zone Research Institute, Dera Ismail Khan, Pakistan.

\section{Experimental procedure}

The experiment was laid out in a randomized complete block design with split-plot arrangement replicated thrice. Tillage treatments were reduced tillage 
(10 $\mathrm{cm}$ depth, one tiller followed by rotavator) and conventional tillage $(20 \mathrm{~cm}$ depth, including disc plough, cultivator, rotavator, and leveling operations). Reduced and conventional tillage were the main plot treatments and irrigation interval (i.e. 10, 15, 20, \& 25 days intervals) the sub plots. Total irrigation water used in irrigation treatments, 10, 15, 20, 25 and 30 days intervals were 1125, 750, 560, 450 and 360 $\mathrm{mm}$, respectively. Each subplot consisted of four rows of $10 \mathrm{~m}$ length and $0.75 \mathrm{~m}$ intra row width. All the subplots were isolated from each other by making bunds around them so that the amount of irrigation for one subplot did not affect the amount of irrigation for another subplot. After wheat harvesting, previous crop residues were incorporated into the soil, with ploughing, operations including tiller, disc plough and rotavator and after well prepared seed bed, cotton was sown with dibbling method (conventional tillage system, CT). The reduced tillage (RT) system consisted of a tiller followed by rotavator, Cotton (cv. Ali Akbar, a standard Bt.variety of cotton for the region) was sown at $75 \mathrm{~cm}$ inter-row and $22.5 \mathrm{~cm}$ intra-row spacing with dibbling method on May 28, 2019. Irrigation was given through canals. Thinning was done 20 days after emergence by leaving one seedling hill ${ }^{-}$ 1. Weeds such as Cynodon dactylon, Conyza canadensis, Tribulus terrestris, and Cyperus rotundus, etc. were controlled with herbicide application [Coast $10.8 \mathrm{EC}$ (a.i. Haloxyfop-R-Methyl $108 \mathrm{~g} \mathrm{l}^{-1}$, dosage $1 \mathrm{~L} \mathrm{ha}^{-1}$, manufacturer, Four Brothers Agri Services, Pakistan)] + [Conquest $24 \mathrm{EC}$ (a.i. Lactofen $168 \mathrm{~g} \mathrm{l}^{-1}$, dosage $450 \mathrm{ml}$ acre $^{-1}$, manufacturer, Kanzo Chemicals, Pakistan)]. All experimental plots received $150-\mathrm{kg}$ N/ha as urea and $60-\mathrm{kg} \mathrm{P} / \mathrm{ha}$ as triple super phosphate. All the phosphorous was applied at sowing, while $\mathrm{N}$ was applied in three split doses, $50 \mathrm{~kg}$ at sowing, $50 \mathrm{~kg}$ at 1st irrigation, and $50 \mathrm{~kg}$ at 3rd irrigation during both the years. The crops were harvested in the last week of November.

\section{Procedure for data recording}

The parameters studied were plant population, plant height $(\mathrm{cm})$, bolls per plant, boll weight $(\mathrm{g})$, seed cotton yield (kg ha-1) and lint percentage/GOT (\%). Six randomly selected plants were tagged in each subplot at maturity for measuring plant height and recorded average plant height $(\mathrm{cm})$, bolls per plant. Total bolls on each plant were counted manually and then averaged. Fifty bolls were randomly collected from each plot and were weighed for recording average boll weight. Seed cotton yields per plot were weighed with an electronic balance and converted into $\mathrm{kg} \mathrm{ha}^{-1}$ as given.

Lint percentage/ginning out turn was recorded by taking seed cotton samples from each plot. After cleaning and sun drying the samples were then ginned with electric ginning machine. The lint attained was weighed and GOT was calculated by the following formula.

$$
\text { Lint percentage }=\frac{\text { Lint yield }(\mathrm{kg})}{\text { Seed cotton yield }(\mathrm{kg})} \times 100
$$

\section{Statistical analysis}

Statistical analysis of the data was performed as per ANOVA techniques and significant results were subjected to LSD test for mean comparison using MSTATC software (MSTATC, 1991).

\section{Results and Discussion}

\section{Plant population $\mathrm{ha}^{-1}$}

ANOVA indicated that plant population had significant response to tillage $(\mathrm{T})$, irrigation intervals (I), while tillage $\times$ irrigation interactions were not significant (Table 2). Main effect revealed that reduced tillage had higher number of plants (32454 per hectare) than conventional tillage (31375 per hectare). Irrigation at 20 days interval gave more plants than other irrigation intervals (Table 3). Tillage methods were important agronomic factor which distress the proper stand establishment, optimum plant population, water saving percentages and seed cotton yield (Bossange et al., 2016). Iirrigation at 20 days interval gave more plants than other irrigation intervals. Uniform plant population was the most important factor to harvest more profitable cotton yield. Adequate plant population was obtained by sowing cotton in optimum irrigation under reduced tillage due to better emergence of seedlings (Coates, 2021).

\section{Plant height $(\mathrm{cm})$}

ANOVA indicated that plant height showed significant response to $\mathrm{T}$ and irrigation intervals, while tillage $\times$ irrigation was not significant (Table 2). Means showed reduced tillage showed taller plant height $(114 \mathrm{~cm})$ than CT $(112 \mathrm{~cm})$. Results revealed that irrigation applied with 10 days interval produced highest plant height $(120 \mathrm{~cm})$ compared to 15, 20 and 25 days irrigation intervals (Table 4). The higher plant height with frequent irrigations might be due to the growing of more nodes and reduced canopy temperature 
Table 2: Mean square values of plant population, Plant height, boll weight, seed cotton yield and lint percentage as affected by tillage and irrigation intervals.

$\begin{array}{llllllll}\text { Source } & \text { D.F } & \text { plant population } & \text { plant height } & \text { bolls per plant } & \text { boll weight } & \text { seed cotton yield } & \text { lint percentage } \\ \text { Replication } & 2 & 9985646 & 0.40000 & 0.0333 & 0.00070 & 1206 & 0.4690 \\ \text { Tillage (T) } & 1 & 8730729^{* *} & 43.20^{* *} & 20.83^{* *} & 0.11^{* *} & 50466^{* *} & 53.8680^{*} \\ \text { Error 1 } & 2 & 122358 & 00001.2 & 0.2333 & 0.00012 & 6680 & 2.4490 \\ \text { Irrigation (I) } & 4 & 22690000^{* *} & 151.8^{* *} & 67.03^{* *} & 0.341^{* *} & 650395^{* *} & 11.6712^{* *} \\ \text { T×I } & 4 & 40977.7^{\text {ns }} & 1.200 & 4.33^{* *} & 0.155^{* *} & 51984^{*} & 0.2655^{\text {ns }} \\ \text { Error 2 } & 16 & 100183 & 1.200 & 1.1333 & 0.00010 & 11848 & 0.6136\end{array}$

Table 3: Impact of tillage and irrigation on plant population per hectare.

\begin{tabular}{|c|c|c|c|}
\hline \multirow{2}{*}{$\begin{array}{l}\text { Irrigation } \\
\text { intervals (days) }\end{array}$} & \multicolumn{2}{|l|}{ Tillage } & \multirow[t]{2}{*}{ Mean } \\
\hline & Reduced & Conventional & \\
\hline 10 & 29233 & 28381 & $28807 \mathrm{~d}$ \\
\hline 15 & 32464 & 31323 & $31893 \mathrm{c}$ \\
\hline 20 & 34602 & 33360 & 33981 a \\
\hline 25 & 33492 & 32529 & $33011 \mathrm{~b}$ \\
\hline 30 & 32476 & 31280 & $31878 \mathrm{c}$ \\
\hline Mean & $32454 \mathrm{a}$ & $31375 \mathrm{~b}$ & \\
\hline
\end{tabular}

LSD0.05 for tillage $=549.57$, irrigation $=387.39$

Table 4: Impact of tillage and irrigation on plant height (cm).

\begin{tabular}{llll}
$\begin{array}{l}\text { Irrigation } \\
\text { intervals (days) }\end{array}$ & $\begin{array}{l}\text { Tillage } \\
\text { Reduced }\end{array}$ & Conventional & Mean \\
10 & 122 & 118 & $120.0 \mathrm{a}$ \\
15 & 117 & 115 & $116.0 \mathrm{~b}$ \\
20 & 116 & 114 & $115.0 \mathrm{~b}$ \\
25 & 110 & 108 & $109.0 \mathrm{c}$ \\
30 & 109 & 108 & $108.0 \mathrm{c}$ \\
Mean & $114.80 \mathrm{a}$ & $112.40 \mathrm{~b}$ & \\
\hline
\end{tabular}

LSD0.05 for tillage $=1.77$, irrigation $=1.3407$

Table 5: Impact of tillage and irrigation on bolls per plant.

\begin{tabular}{llll}
$\begin{array}{l}\text { Irrigation intervals } \\
\text { (days) }\end{array}$ & $\begin{array}{l}\text { Tillage } \\
\text { Reduced }\end{array}$ & $\begin{array}{l}\text { Conventional } \\
\text { Mean }\end{array}$ \\
10 & $18 \mathrm{~cd}$ & $18 \mathrm{~cd}$ & $18.0 \mathrm{~b}$ \\
15 & $19 \mathrm{c}$ & $19 \mathrm{c}$ & $19.0 \mathrm{~b}$ \\
20 & $25 \mathrm{a}$ & $21 \mathrm{~b}$ & $23.0 \mathrm{a}$ \\
25 & $17 \mathrm{de}$ & $15 \mathrm{f}$ & $16.0 \mathrm{c}$ \\
30 & $15 \mathrm{ef}$ & $13 \mathrm{~g}$ & $14.2 \mathrm{~d}$ \\
\hline Mean & $18.9 \mathrm{a}$ & $17.2 \mathrm{~b}$ & \\
\hline
\end{tabular}

LSD0.05 for tillage $=0.7589$, irrigation $=1.3030$, tillage $\times$ irriga tion $=1.8427$ under reduced tillage as reported by Idowu et al (2019). Siskani et al. (2015) communicated similar findings who reported that water stress reduced plant height of cotton. They further reported that irrigation applied as per requirement of the crop resulted in higher plant height.

\section{Bolls plant ${ }^{-1}$}

Bolls plant ${ }^{-1}$ was significantly influenced by tillage (T), I, and $\mathrm{T} \times \mathrm{I}$ (Table 2). Tillage mean revealed that reduced tillage showed higher bolls plant ${ }^{-1}$ than conventional tillage (Table 5). Reduced tillage showed higher bolls plant ${ }^{-1}$ than conventional tillage system, most likely due to more favourable soil micro-climate with regard to soil moisture conservation, nutrients supply, and light transmission. The optimum utilization of resources by crop plants might have caused higher bolls plant ${ }^{-1}$ in reduced tillage compared to conventional tillage system (Blaise, 2011). Irrigation with 20 days interval produced significantly more bolls per plant compared to all other irrigation intervals. Interaction effect indicated that reduced tillage in combination with 20 days irrigation interval had the highest number of bolls per plant. Irrigation with 20 days interval had probably more favorable moisture content than lower or higher irrigation interval under reduced tillage cotton which resulted in the development of more fruiting bodies (Li et al., 2019). Bolls per plant increased with an increase in irrigation intervals from 10 to 20, however, further increase beyond 20 days interval may not be productive for the reduced rate of boll growth. Further, they reported the number of bolls as a genetic parameter that differed. Siskani et al. (2015) communicated similar findings who reported that water stress reduced plant height of cotton. They further reported that irrigation applied as per requirement of the crop resulted in higher bolls per plant. 
Table 6: Impact of tillage and irrigation on boll weight $(g)$.

\begin{tabular}{llll}
$\begin{array}{l}\text { Irrigation } \\
\text { intervals (days) }\end{array}$ & $\begin{array}{l}\text { Tillage } \\
\text { Reduced }\end{array}$ & Conventional & \\
\hline 10 & $2.12 \mathrm{e}$ & $2.32 \mathrm{c}$ & $2.22 \mathrm{~d}$ \\
15 & $2.43 \mathrm{~b}$ & $2.32 \mathrm{c}$ & $2.38 \mathrm{~b}$ \\
20 & $3.09 \mathrm{a}$ & $2.44 \mathrm{~b}$ & $2.77 \mathrm{a}$ \\
25 & $2.32 \mathrm{c}$ & $2.22 \mathrm{~d}$ & $2.27 \mathrm{c}$ \\
30 & $2.14 \mathrm{e}$ & $2.20 \mathrm{~d}$ & $2.17 \mathrm{e}$ \\
Mean & $2.42 \mathrm{a}$ & $2.30 \mathrm{~b}$ & \\
\hline
\end{tabular}

LSD0.05 for tillage $=0.0174$, irrigation $=0.0123$, tillage $\times$ irriga tion $=0.0174$

Bolls weight-gms

Bolls weight was affected significantly by $\mathrm{T}$, I and $\mathrm{T}$ $\times$ I interaction (Table 2). Reduced tillage had heavier boll weight than conventional tillage (Table 6). The better performance of reduced tillage may be attributed toward better establishment of crop stand in comparatively favourable soil environment and more allocation of resources to boll formation compared to conventional tillage for loss of nutrients and moisture. Bossange et al. (2016) also observed greater boll weight in conservation or reduced tillage system. The favourable soil physical environment may have contributed to the significant improvements in boll weight under reduced tillage (Blaise, 2011). Irrigation with 20 days interval resulted in heavier bolls compared to 10,15, 25 and 30 days intervals. Interactions indicated that reduced tillage with 20 days irrigation interval depicted highest boll weight. Boll weight fluctuates between values of 2.2 and 2.8 with irrigation interval from 10 to 20 days. Results indicates that 20 days irrigation interval is optimum for boll weight as a further increase in irrigation interval up to 30 days may result in reduced growth rate. This was probably because of increased translocation of photosynthates from source to sink (boll) due to more favourable soil environment for uptake of nutrients compared to all other irrigation regimes (as more moisture favoured more vegetative growth rather than reproductive growth (Omololu et al., 2020). Heavier boll weight with 25 days irrigation interval was perhaps due to more favorable moisture condition for lesser evaporative losses from reduced tillage cotton as reported by Yang et al. (2016). Siskani et al. (2015) communicated similar findings who reported that water stress reduced plant height of cotton. They further reported that irrigation applied as per requirement of the crop resulted in higher BW.

Table 7: Impact of tillage and irrigation seed cotton yield $\left(k g h a^{-1}\right)$.

\begin{tabular}{llll}
$\begin{array}{l}\text { Irrigation intervals } \\
\text { (days) }\end{array}$ & $\begin{array}{l}\text { Tillage } \\
\text { Reduced }\end{array}$ & Conventional & Mean \\
\hline 10 & $1600 \mathrm{ef}$ & $1519 \mathrm{f}$ & $1559 \mathrm{c}$ \\
15 & $1935 \mathrm{bc}$ & $1834 \mathrm{~cd}$ & $1885 \mathrm{~b}$ \\
20 & $2256 \mathrm{a}$ & $2041 \mathrm{~b}$ & $2149 \mathrm{a}$ \\
25 & $1738 \mathrm{de}$ & $1227 \mathrm{~g}$ & $1482 \mathrm{c}$ \\
30 & $1530 \mathrm{f}$ & $1141 \mathrm{~g}$ & $1336 \mathrm{~d}$ \\
Mean & $1812 \mathrm{a}$ & $1553 \mathrm{~b}$ & \\
\hline
\end{tabular}

LSD0.05 for tillage $=128.41$, irrigation $=133.22$, tillage $\times$ irriga tion $=188.40$

\section{Seed cotton yield $\left(\mathrm{kg} \mathrm{ha}^{-1}\right)$}

Results revealed that tillage, irrigation intervals, and tillage $\mathrm{x}$ irrigation interaction had significant effects on seed cotton yield (Table 2). Main effects revealed that reduced tillage gave highest seed cotton yield (Table 7). The results revealed that all the two tillage systems had identical response to the seed cotton yield indicating that reduced tillage practices may be productive and economical if irrigation is not a limiting factor. Due to the cost-cutting of production, reduced tillage may be more economical and environmentally safe besides conservation of resources. In the long term, reduced tillage in combination with optimum irrigation interval may improve soil properties with significant improvement in the seed cotton yield (Idowu et al., 2015; Coates, 2021). Siskani et al. (2015) communicated similar findings who reported that water stress reduced plant height of cotton. Seed cotton increased with an increase in irrigation intervals from 10 to 20 , however, further increase beyond 20 days interval may not be productive for the reduced rate of boll growth. Further, they reported the number of bolls as a genetic parameter that differed. They further reported that irrigation applied as per requirement of the crop resulted in higher seed cotton. Results revealed that 20 days irrigation interval proved to be more productive regarding seed cotton yield than all other intervals. Irrigation intervals 10 to 15 days had lower seed cotton yield perhaps due to excessive soil moisture that led to more dynamic vegetative growth rather than seed cotton yield. Besides higher seed cotton yield, irrigation with 20 days interval was cost-effective as it saved more water (60\%) when compared with 10 and 15 days interval (check treatment for 
comparison). It can be predicted from results that irrigation interval beyond 20 days may not be productive for the reduced rate of growth as a consequence of low moisture stress. Lower seed cotton yield with shorter irrigation intervals (10 to 15 days) might be due to excess moisture stress that led to flowers and bolls dropping (Siskani et al., 2015). Similar findings were conveyed by Sahito et al. (2015) who reported that irrigation interval more than 20 days produced higher seed cotton yield. Tan et al. (2018) had comparable findings who reported that moderate volume of irrigation would be more economical than excessive use of water. Furthermore, they reported that varieties with different genetic background had different seed cotton yields.

Table 8: Impact of tillage and irrigation lint \%age.

\begin{tabular}{|llll|}
$\begin{array}{l}\text { Irrigation intervals } \\
\text { (days) }\end{array}$ & $\begin{array}{l}\text { Tillage } \\
\text { Reduced }\end{array}$ & Conventional \\
\hline 10 & 36.17 & 33.33 & $34.75 \mathrm{bc}$ \\
\hline 15 & 37.13 & 34.23 & $35.68 \mathrm{~b}$ \\
20 & 39.07 & 36.27 & $37.67 \mathrm{a}$ \\
25 & 36.13 & 33.20 & $34.67 \mathrm{c}$ \\
\hline 30 & 35.10 & 33.17 & $34.13 \mathrm{c}$ \\
\hline Mean & $36.72 \mathrm{a}$ & $34.04 \mathrm{~b}$ & \\
\hline
\end{tabular}

LSD0.05 for tillage $=2.4587$, irrigation $=0.9587$

\section{Lint percentage}

Lint percentage was significantly affected by tillage, irrigation intervals, while their interaction was not significant (Table 2). Mean values for the tillage revealed that reduced tillage produced highest lint \%age. Results showed that irrigation with 20 days interval produced highest lint \%age among all other irrigation intervals (Table 8). Since bolls plant ${ }^{-1}$ and boll weight are positively correlated with lint yield, reduced tillage might have higher lint/GOT probably due to its higher bolls plant ${ }^{-1}$ and higher boll weight in interaction with optimum irrigation (20 days interval) (Zhang et al., 2020). The results of the present investigation are in line with previous findings by $\mathrm{Li}$ et al. (2020) who reported that GOT was associated with the genetic makeup of a variety. Siskani et al. (2015) communicated similar findings who reported that water stress reduced plant height of cotton. They further reported that irrigation applied as per requirement of the crop resulted in higher lint.

\section{Conclusion and Recommendations}

Reduced tillage produced $38.9 \%$ more bolls per plant, $45.8 \%$ greater boll weight, $41 \%$ higher seed cotton yield and $8.1 \%$ higher lint \%age. Irrigation with 20 days interval can conserve $60 \%$ water compared to usual application of irrigation with 10 days interval for the crop life cycle of growth and development.

\section{Novelty Statement}

The study depicts that reduced tillage with 20 days irrigation interval is advantageous and adaptable in agro-ecological conditions of Dera Ismail Khan.

\section{Author's Contribution}

Niamat Ullah Khan: Conducted the research. Umbreen Shahzad: Supervised the study and provided technical at every step.

Azhar Abbas Khan, Muhammad Kashan and Shitab Khan: Revised the manuscript.

Sami Ullah: Analysed the lab work

Muhammad Arshad Farooq: Asisted in prepration of final draft.

\section{Conflict of interest}

The authors declares that there is no conflict of interests regarding the publication of this article.

\section{References}

APTMA. 2018. All Pakistan Textile Mills Association. World cotton and non-cotton fiber consumption. Available online at http://www. aptma.com

Ashraf, S., A.H. Sangi, Z.Y. Hassan and M. Luqman. 2018. Future of cotton sector in Pakistan: A 2025 Outlook. Pak. J. Agric. Res. 31(2): 145-150. https://doi.org/10.17582/journal. pjar/2018/31.2.145.150

Azevedo, R.A., P.L. Gratão, C.C. Monteiro and R.F. Carvalho. 2019. What is new in the research on cadmium-induced stress in plants? Food Energ. Secur. 1: 133-140. https://doi. org $/ 10.1002 /$ fes 3.10

Blaise, D. 2011. Tillage and green manure effects on Bt transgenic cotton (Gossypium hirsutum L.) hybrid grown on rainfed Vertisols of central India. Soil Till Res. 114:86-96. https://doi. org/10.1016/j.still.2011.04.008 
Bossange, A.V., K.M. Knudson, A. Shrestha, R. Harben and J.P. Mitchell. 2016. The Potential for conservation tillage adoption in the San Joaquin Valley, California: A Qualitative Study of Farmer Perspectives and Opportunities for Extension. PLoS ONE, 11, e0167612. https:// doi.org/10.1371/journal.pone.0167612

Coates, W.E. 2021. Reduced Tillage Systems for Irrigated Cotton: Is Soil Compaction a Concern? Appl. Eng. Agric. 17: 273-279.

DeLaune, P.B., P. Mubvumba, S. Ale and E. Kimura. 2020. Impact of no-till, cover crop, and irrigation on Cotton yield. Agric. Water Manage. 232: 1127-1140. https://doi.org/10.1016/j. agwat.2020.106038

Farooq, O., K. Mubeen, A.A. Khan and S. Ahmad. 2020. Sowing methods for cotton production. In cotton production and uses; Springer Science and Business Media LLC: Berlin/ Heidelberg, Germany. pp. 45-57. https://doi. org/10.1007/978-981-15-1472-2_4

Hulugalle, N.R., D.B. Nehl and T.B. Weaver. 2019. Soil properties, and cotton growth, yield and fiber quality in three cotton-based cropping systems. Soil Till. Res. 75: 131-141. https://doi. org/10.1016/j.still.2003.07.003

Idowu, O.J., Sultana, S. Darapuneni, M.; Beck, L. and Steiner, R. 2019. Short-term Conservation Tillage effects on corn silage yield and soil quality in an irrigated, Arid Agroecosystem. Agronomy, 9: 455. https://doi.org/10.3390/ agronomy 9080455

Li, M., Y. Du and F. Zhang .2019. Simulation of cotton growth and soil water content under film-mulched drip irrigation using modified CSM-CROPGRO-cotton model. Agric. Water Manag. 124-138. https://doi.org/10.1016/j. agwat.2019.03.041

Li, M., J. Xiao, Y. Bai, Y. Du, F. Zhang, H. Cheng and H. Wang. 2020. Response mechanism of cotton growth to water and nutrients under drip irrigation with plastic mulch in southern Xinjiang. Sens. Appl. Agric. and Environ. Monit. https://doi.org/10.1155/2020/2575162

MNFSR. 2015. Ministry of National Food Security and Research, GoP, Islamabad. Pp. 1-3.

MSTATC. 1991. MSTATC package, version 1. Michigan State Univ., USA.
Nouri, A., Lee, J., Yin, X., Tyler, D.D. and Saxton, A.M. 2019. Thirty-four years of no-tillage and cover crops improve soil quality and increase cotton yield in Alfisols, Southeastern USA. Geoderma 337": 998-1008. https://doi. org/10.1016/j.geoderma.2018.10.016

Omololu, J.I., S. Sultana, M. Darapuneni, L. Beck, R. Steiner and M. Omer. 2020. Tillage Effects on cotton performance and soil quality in an irrigated arid cropping system. Agric. 10: 531. https://doi.org/10.3390/agriculture10110531

Sahito, A., Z.A. Baloch, A. Mahar, S.A. Otho, S.A. Kalhoro, A. Ali, F.A. Kalhoro, R.N. Soomro and F. Ali. 2015. Effect of water stress on the growth and yield of cotton crop. Am. J. Plant Sci. 6: 1027-1039. https://doi.org/10.4236/ ajps.2015.67108

Siskani, A., M.J. Seghatoleslami and G. Moosavi. 2015. Effect of deficit irrigation and nano fertilizers on yield and some morphological traits of cotton. Biol. Forum, Int. J. 7(1): 1710-1715.

Statista. 2018. Cotton production by country worldwide in 2017/2018 (in 1,000 metric tons). https://www.statista.com/statistics/263055/ cotton-production-worldwide-by-topcountries/

Tan, S., Q.Wang, J. Zhang, Y. Chen, Y. Shan and D. Xu. 2018. Performance of AquaCrop model for cotton growth simulation under film-mulched drip irrigation in southern Xinjiang, China. Agric. Water Manage. 196: 99-113. https://doi. org/10.1016/j.agwat.2017.11.001

Thorp, K.R., A.L. Thompson and K.F. Bronson. 2020. Irrigation rate and timing effects on Arizona cotton yield, water productivity, and fiber quality. Agric. Water Manage. 234: 106146. https://doi.org/10.1016/j.agwat.2020.106146

Yang, P., H. Hu, F. Tian, Z. Zhang and C. Dai. 2016. Crop coefficient for cotton under plastic mulch and drip irrigation based on eddy covariance observation in an arid area of northwestern China. Agric. Water Manage. 171: 21-30. https://doi.org/10.1016/j.agwat.2016.03.007

Zhang, J., Idowu, O.J., Wedegaertner, T. 2020. Registration of Glandless 'NuMex COT 17 GLS' Upland cotton cultivar with fusarium wilt race 4 resistance. J. Plant Regist. 14: 1-9. https://doi. org/10.1002/plr2.20020 